\title{
Nabucco in Zion: Place, Metaphor and Nationalism in an Israeli Production of Verdi's Opera ${ }^{\star}$
}

\section{RACHEL ORZECH}

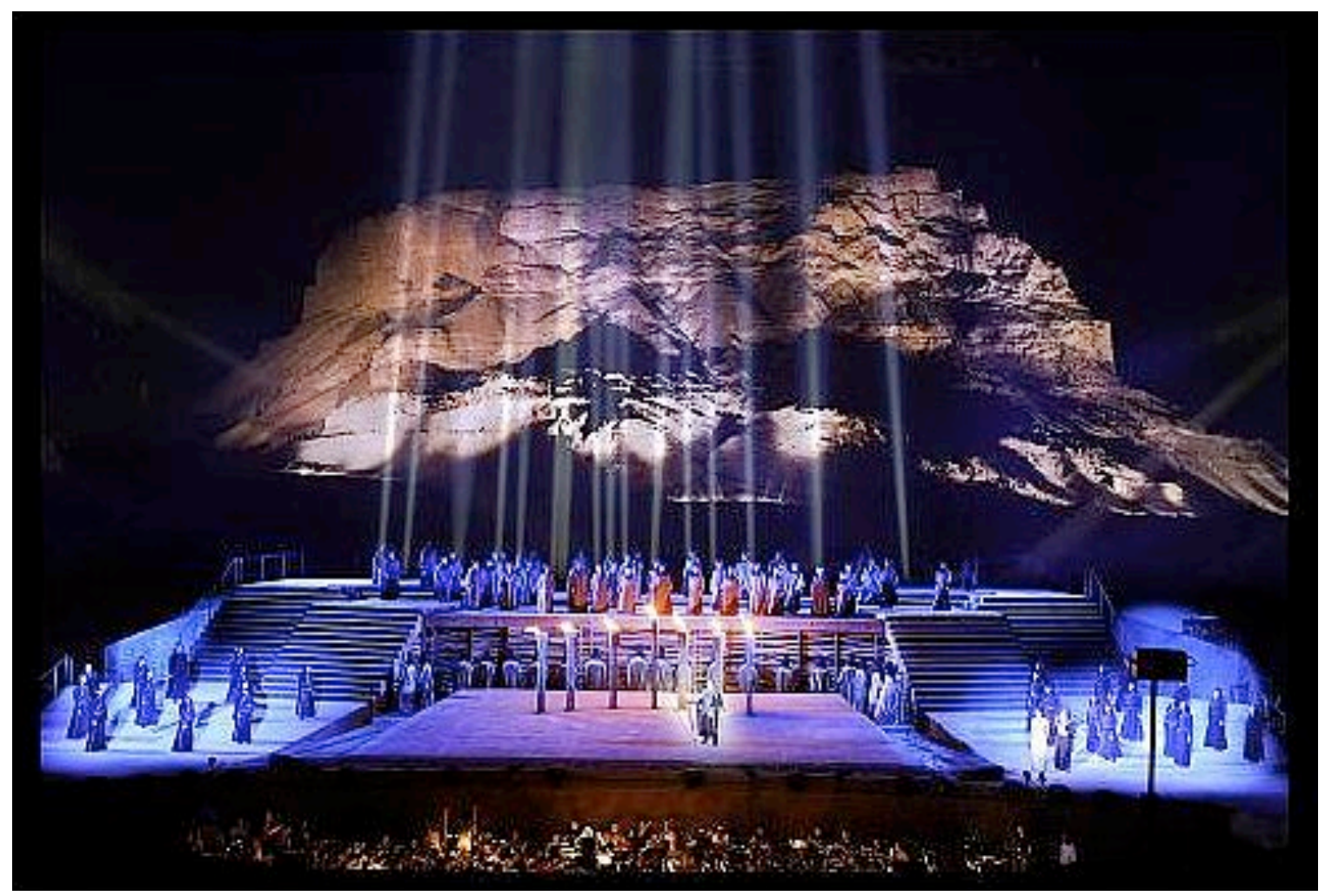

Figure 1: Nabucco performed on the outdoor stage with Mount Masada in the background. Photograph by Yossi Zwecker.

In June 2010, the Israeli Opera staged a spectacular production of Verdi's Nabucco at the foot of Masada, a UNESCO World Heritage site of Roman ruins on the edge of the Judaean desert, overlooking the Dead Sea. The site-specific production was not only significant in technical and organizational terms; it was an immensely powerful event that combined opera, national mythology, collective memory, and political circumstances to make a compelling political statement. It transformed a work that has long been understood as symbolic of Italian national pride into an operatic event infused with Israeli nationalism. In this essay I argue that this production of Nabucco in Israel was able to succeed as a nationalist project only because of the work's reception history in Italy: the history of understanding the work as a metaphor for

\footnotetext{
* I wish to thank Kerry Murphy, David Larkin, Reuben Brown and the anonymous readers for their advice and assistance in the preparation of this article, and Sivan Gabrielovich, Alexander O'Sullivan, and Don King for assistance with translations from Italian and Hebrew.
} 
the Risorgimento movement in nineteenth-century Italy, and the persistence of this interpretation into the twenty-first century, allowed Nabucco to be interpreted as a Zionist story that resonated with Jewish and Israeli audiences. Yet at the same time, this success was achieved through what we might call a demetaphorization of the work in which the layer of Italian political mythology was displaced by a Jewish Israeli myth, one that was equally fictitious but nevertheless responded to the original plot on a less metaphorical level. The performance site and its associated mythology was crucial to the work's transformation from a symbol of Italian nationalism to an Israeli event that perpetuated the Zionist project of establishing a historical continuity between Jewish life in the Holy Land during antiquity and the existence of the modern Jewish state today. While relying on the history of Nabucco as a metaphor for Italian patriotism, the Israeli Opera was able to simultaneously exploit the physical, geographical, political, and symbolic potential of Masada as a performance site to create a politically and emotionally powerful operatic event. I begin by examining the two mythologies invoked by this event: one that is concerned with the associations between Verdi's Nabucco and the Risorgimento movement and another that regards the ancient story of Masada's Jewish rebels as symbolic of Israel's current political predicament.

\section{Nabucco in Italy}

Although Nabucco is sometimes referred to as Verdi's "Jewish opera," it has been most commonly understood to represent the Italian nationalist aspirations of the nineteenth century. The work's famous Act III chorus, "Va, pensiero," developed legendary status as a symbol of and metaphor for Italian patriotism and the Risorgimento movement, which fought broadly for a unified Italy liberated from Austrian rule. By the time of his death in 1901, Verdi occupied an almost mythical place in Italian culture and was known as the bard of the Risorgimento; a month after his death, as his coffin was transferred to the Casa di Riposo per Musicisti in Milan, hundreds of thousands of people reportedly lined the streets as Arturo Toscanini conducted a chorus singing "Va, pensiero." From this time on, the chorus has remained a powerful symbol of Italian patriotism and of Verdi's status as its figurehead. Its fame is based on the assumption that the chorus had been wildly popular in Italy from the time of its premiere in 1842 because it was understood as a covert political statement about the Italian people's longing for freedom from foreign rule. Until the 1990s, many Verdi scholars and biographers made similar assumptions about the chorus's importance and popularity during the Risorgimento, and thus about the significance of Verdi's involvement in Italian politics. ${ }^{2}$

In the last twenty-five years, however, this view has been challenged, notably by British musicologist Roger Parker, who first raised doubts in the late 1980s about the extent to which Verdi was politically engaged, and whether or not members of the Risorgimento movement understood his music to be supportive or emblematic of their cause. ${ }^{3}$ Musicologists did not unanimously accept Parker's arguments,

\footnotetext{
${ }^{1}$ Mary Jane Phillips-Matz, Verdi: A Biography (Oxford: Oxford University Press, 1993), 765.

${ }^{2}$ George Martin mentions, for example, early Italian biographers such as Gino Monaldi, as well as the twentieth-century biographer Franco Abbiati; see George Martin, "Verdi, Politics, and 'Va, pensiero': The Scholars Squabble," Opera Quarterly 21, no. 1 (2005): 113.

${ }^{3}$ Parker's initial doubts were expressed briefly in his notes on the critical edition of Nabucco and elaborated upon in later publications. See Roger Parker, "The Critical Edition of Nabucco," Opera Quarterly 5, no. 2/3 (1987): 91-8; "The Exodus of Nabucco (1842-44)" in Studies in Early Verdi 1832-1844: New Information and Perspectives on the Milanese Musical Milieu and the Operas from Oberto to Ernani (New York: Garland Publishing, 1989), 111-41; "Arpa d'or dei Fatidici Vati": The Verdian Patriotic Chorus in the 1840s (Parma: Istituto Nazionale di Studi Verdiani, 1997).
} 
and his work sparked scholarly debate about Verdi and Italian politics. "Va, pensiero," in which King Nebuchadnezzar's exiled Hebrew slaves yearn for freedom and their homeland, lies at the center of this debate because of its popular image as a metaphor for the aspirations of the Risorgimento movement, largely due to the belief that the chorus carried a hidden political meaning that was recognized on its very first hearing in Milan in 1842. Parker argues that the association between Verdi and the Risorgimento in the popular imagination owes more to nostalgia than to history and thus must be reassessed. He writes:

a common thread in Verdi reception ... presents Verdi as an artist whose work must be constantly regarded through the filter of a political and social background ... This image [of Verdi as symbol of the Risorgimento] is basic to the popular view of Verdi; and ... the popular view has received frequent support from the scholarly community. ${ }^{5}$

Parker disputes this view_as well as more specific assumptions about the significance of "Va, pensiero" as a metaphor for the Italian people's political condition in the $1840 \mathrm{~s}$ - on the basis of research he carried out to produce the critical edition of Nabucco as well as a study of the opera's Italian reception during the 1840s. ${ }^{6}$ His research reveals that while Nabucco was quite a popular work, "Va, pensiero" was not singled out by either audiences or critics in any noticeable way until several years after the opera's premiere and the 1848 revolutions. ${ }^{7}$ He concludes that the idea of "Verdi and the Risorgimento' has become a hoary interdisciplinary cliché," ${ }^{8}$ and although not all scholars would support this statement, most now accept that the rise of this chorus to mythological status did not take place until much later in the century than previously thought. Thus, the significance of Nabucco and "Va, pensiero" to the Risorgimento movement is a mythological invention rather than a historical fact.

Nevertheless, this reassessment of a crucial aspect of Verdi studies has had little impact on the general Italian public. The chorus has been a popular symbol of the Risorgimento movement since Verdi's death, and since then the myth of Verdi as the representative of Italian patriotism, and of "Va, pensiero" as the ultimate expression of the composer's patriotic feeling, has stayed very much alive for opera lovers in Italy and elsewhere. We need only look back as far as March 2011 to a performance of Nabucco in Rome, conducted by Riccardo Muti in celebration of the 150th anniversary of Italian unification. The production was preceded by a speech in which the mayor of Rome appeared on stage and criticized recent cuts to arts and culture funding by Silvio Berlusconi's government. ${ }^{9}$ It has long been a (somewhat controversial) tradition in Italian opera houses for "Va, pensiero" to be repeated as an encore in the midst of the opera's third act. Thus, at Muti's performance in Rome, the audience reportedly erupted with the predictable calls for an encore and cries of "Viva Italia!" and "Viva Verdi!" at the end of the chorus. In a gesture that was described by one journalist as "a national catharsis," ${ }^{10}$ Muti turned to the audience and said (see Video 1):

\footnotetext{
${ }^{4}$ For example, George Martin and Philip Gossett have each argued that while Parker's arguments have some merit, earlier scholarship was not as flawed as Parker claims. See Martin, "Verdi, Politics, and "Va, pensiero"'; and Philip Gossett, “'Edizioni Distrutte' and the Significance of Operatic Choruses during the Risorgimento" in Opera and Society in Italy and France from Monteverdi to Bourdieu, ed. Victoria Johnson, Jane F. Fulcher, and Thomas Ertman (Cambridge: Cambridge University Press, 2007), 181-242.

${ }^{5}$ Parker, "Arpa d'or dei Fatidici Vati," 19-20.

${ }^{6}$ Parker, "Critical Edition of Nabucco," 93-4; and “Va, pensiero' and the Insidious Mastery of Song” in Leonora's Last Act: Essays in Verdian Discourse (Princeton: Princeton University Press, 1997), 32-3.

${ }^{7}$ Parker, "Arpa d'or dei Fatidici Vati,” 29.

${ }^{8}$ Ibid..

9 James Bone, "Riccardo, the Lionheart," The Times, 22 March 2011, Factiva, http://global.factiva.com.ezproxy.lib.unimelb.edu.au/ha/default.aspx.

${ }^{10}$ Ibid.
} 
I'm not 30 years old and so I've had my life. But I am, as an Italian who travels the world, very pained by what is happening ... This evening, when the choir sang "Oh my country, so beautiful and lost," I thought that if we kill the culture upon which Italy was founded then our country will truly be "beautiful and lost." 11

In a later interview Muti said, "when we arrived at 'Va pensiero' I immediately felt the atmosphere became tense in the audience .. . They were thinking: everything that made our country great in the past is lost." 12 The conductor then invited the audience to join in the encore of the chorus: "If you would like to join in as well, we will do it altogether." ${ }^{\prime 3}$ And they did. One could not find a more blatant example of the continuing power of this opera to elicit patriotic feeling in twenty-first-century Italy; its potential to be interpreted as a political statement clearly remains undiminished, and as we shall see, it is not only in Italy that this potential can be exploited.

Video 1: Conductor Riccardo Muti's speech during a performance of Nabucco in Rome on 12 March 2011.

View at: http://dx.doi.org/10.3998/mp.9460447.0009.103

\section{Nabucco in Israel, and Masada as Performance Site}

Since its founding in 1985, the Israeli Opera has staged Nabucco four times: 1995, 1996, 2003, and then 2010 at Masada. Additionally, in 1988 an outdoor performance of Nabucco was planned as part of the festivities organized to celebrate the state of Israel's fortieth anniversary. The event was to be run by a private company called Opera on Original Sites, and the London Royal Philharmonic Orchestra was hired. The opera was to be staged in an amphitheater at the Sultan's Pool, just outside the walls of Old Jerusalem, and was expected to attract large numbers of foreign tourists-enough for Israeli airlines to schedule extra flights. ${ }^{14}$ But the production was cancelled just two months before opening night because of continuing unrest in the West Bank due to the Palestinian uprising. However, an Israel Philharmonic Orchestra concert at the foot of Masada, which had been planned as the finale of the year's celebrations, went ahead. The main work advertised on the program was Gustav Mahler's Resurrection Symphony, chosen because it symbolized "the return of the Jewish people to the homeland," according to the executive producer Benny Boret. "Masada in our history," he stated, "means death, tragedy, the end of the world, everything to the contrary of hope. This year we are celebrating 40 years of return, despite that. ${ }^{16}$ The Masada site deeply

\footnotetext{
11 "lo non ho trent'anni e quindi la mia vita l'ho fatta. Ma sono molto, come italiano, che gira il mondo, molto addolorato per quello che sta avvenendo ... Ma in questa sera, mentre il coro cantava 'Oh mia patria, sì bella e perduta,' ho pensato che si noi uccidiamo la cultura su cui è fondata la soglia dell'Italia, veramente sarà la nostra Patria bella e perduta.” Muti seems to have made this speech at more than one of the performances in this season, and there are varying reports of exactly what he said. The speech quoted here is taken from a video of the opening night on 12 March 2011. "Va pensiero... Riccardo Muti Speaking About Italian Culture, Opera di Roma, 12.03.2011," YouTube, 18 March 2011, http://www.youtube.com/watch?v=G gmtO6JnRs.

${ }^{12}$ Bone, "Riccardo, the Lionheart."

13 "Va Pensiero ... Riccardo Muti," Youtube.

${ }^{14}$ James T. Yenckel, “The Celebrations and the Safety Concerns,” Washington Post, 21 February 1988, LexisNexis, www.lexisnexis.com/hottopics/lnacademic.

${ }^{15}$ Although it is difficult to argue that there is anything explicitly Jewish about Mahler's music, and there is no evidence that the Second Symphony contains any reference to the Jewish people, the composer has been adopted by Israelis as a kind of "national asset." See Talia Pecker Berio, "Mahler's Jewish Parable" in Mahler and his World, ed. Karen Painter (Princeton: Princeton University Press, 2002), 91.

${ }^{16}$ Carol Rosenberg, “'Resurrection' to Ring Out in Masada," Chicago Tribune, 29 September 1988, http://articles.chicagotribune.com/1988-09-29/features/8802030012 1 masada-fortress-jewish-national-fund.
} 
affected audience members, and Boret's message of triumphant return (or resurrection!) clearly rang true for many. A French Jewish woman who attended the concert told a reporter: "For me this is an affair of the heart ... I suffered through the war, and I lost most of my family in Auschwitz. And so, this place means survival-the survival of Israel. ${ }^{17}$ These fragments of the performance history of Nabucco in Israel show how both the site of Masada and the opera Nabucco had previously been chosen as important symbols of national pride and celebration although they were not combined until the 2010 production. $^{18}$

\section{The Masada Myth}

The ancient ruins on the mountain of Masada in present-day Israel are the remains of a fortress that was probably built by Herod the Great in the first century BCE. According to Israeli national mythology, the abandoned fortress provided shelter in the first century CE for Jews fleeing Jerusalem after the Roman conquest of the city during the Jewish Great Revolt. With Jerusalem conquered, the Romans set out to attack any remaining outposts held by Jewish warriors and refugees. The fortress on Masada was the last of these outposts to survive. The well-known mythical narrative refers to the Masada Jews as heroic Zealots or Jewish warriors who, when besieged by the Roman army, bravely resisted the siege for months until the army breached the fortress walls. At this point, according to the myth, the Zealots on Masada realized they faced certain death or enslavement. Choosing to die free rather than submit to their enemy, their leader commanded the men to kill their wives and children before killing each other. When the Roman soldiers finally reached the living quarters within the fortress, they were astonished to find themselves surrounded by dead bodies. ${ }^{19}$ This popular version of the Masada narrative has provided Zionism with a nationbuilding myth since before the founding of the state of Israel, and continues to be understood by many Israelis as a historical narrative rather than a mythological one. Yet scholars such as Israeli sociologist Nachman Ben-Yehuda have denounced the myth as a "fabricated moralistic claim that has served as a cornerstone of an entire nation, ${ }^{20}$ and since the 1960s, historians, archaeologists, sociologists, and other scholars have re-examined the narrative from an increasingly critical perspective.

The evolution of the significance of Masada began in the 1920s when a work entitled The Wars of the Jews, written by first-century historian Josephus Flavius, was first published in modern Hebrew. Around the same time, groups of Jews living in Palestine began trekking through the desert and climbing the mountain, which was at that time a dangerous undertaking. The availability of Josephus's account and the publication of a Hebrew poem titled "Masada" by Jewish poet Yitzhak Lamdan combined to arouse

\footnotetext{
${ }^{17}$ Stephen Franklin, 'Igniting the Spirit of Masada: Concert Wins Hearts at Historic Israeli Fortress', Chicago Tribune 16 October 1988, accessed 9 May 2012, http://articles.chicagotribune.com/1988-10-16/features/8802080042_1_masada-israelisjews.

${ }^{18}$ There is also a history of Nabucco being used as a means of understanding and exploring relationships between Jews and non-Jews in a society. The most obvious case in point would be the opera's performance and reception history in Germany, examined by Gundula Kreuzer in some detail. See Gundula Kreuzer, Verdi and the Germans: From Unification to the Third Reich (Cambridge: Cambridge University Press, 2010), esp. 221-229, 245; also, Lily E. Hirsch, A Fewish Orchestra in Nazi Germany: Musical Politics and the Berlin Culture League (Ann Arbor: University of Michigan Press, 2010), 125-9. Timothée Picard also draws attention to a 1980 documentary that follows a site-specific production of Nabucco in Israel, performed by artists from the Deutsche Oper Berlin who play the persecuted Jews, and Jewish Israelis who perform the parts of the Babylonian oppressors. See Picard, Verdi-Wagner. Imaginaire de l'opéra et identités nationales (Arles: Actes Sud, 2013), 16-17.

${ }^{19}$ Nachman Ben-Yehuda, The Masada Myth: Collective Memory and Mythmaking in Israel (Madison: University of Wisconsin Press, 1995), 9-14.

${ }^{20}$ Ben-Yehuda, Masada Myth, 3. In this book, Ben-Yehuda describes his feelings of anger and betrayal when he first realized that the story of Masada that he had grown up with was historically inaccurate. Ibid., 3-5.
} 
interest in the story. ${ }^{21}$ Lamdan's poem was to prove extremely popular over the following decades, and one line in particular-“Masada shall not fall again!”-became a famous national motto. Yael Zerubavel describes the poem as "one of the major literary works of great ideological influence upon the Zionist youth" during the pre-state period. ${ }^{22}$ Indeed, Zionist youth living in Palestine played a significant role in developing the Masada myth in its early stages before the founding of the state of Israel. Youth groups and school classes began hiking to the area long before it attracted the interest of archaeologists in the 1950s. ${ }^{23}$ Trips to Masada eventually became pilgrimages in which young Hebrews completed the hike as a rite of passage and a means of physically "knowing the land," reclaiming their roots, and establishing ownership of a land that they believed was rightfully theirs. ${ }^{24}$ These expeditions were a fundamental product of the Zionist ideology of that pre-state period, which sought to create a new kind of Jew-one who could work on the land and fight for survival. Shmaria Guttman, an archaeologist and central figure in Zionist youth movements, first hiked to Masada in 1933 and was struck by its potential for inspiring young Jews to "fight to the end." 25 In the 1940s he began organizing seminars about Masada and leading youth group expeditions to the site. He later wrote:

A generation of youth was raised by Masada. This is the generation that created the state, the generation of defense in its various manifestations. Masada has been the source of power and courage to liberate the country, to strike roots, and defend the whole territory. ${ }^{26}$

In the decades following the Holocaust and the creation of the Jewish state, the mythological heroes of Masada served as a kind of heroic counter-model to the persecuted Jews of the diaspora, who were condemned by many in the Palestinian Jewish community for weakness, submission, and having behaved like "sheep to the slaughter." From this perspective, the Masada warriors were courageous heroes because they fought to the death instead of submitting to defeat, humiliation, and slavery. They were an ideal model for the "New Hebrews" who began to define themselves in opposition to Jews who had chosen life in exile. ${ }^{27}$

Interest in the Masada story greatly increased both in and outside Israel following extensive archaeological excavations at the site between 1963 and 1965. What began as an archaeological project rapidly transformed into an extraordinary memory-making exercise involving volunteers from all over the world and watched closely by the Israeli public. Ben-Yehuda estimated in 1996 that the project cost the equivalent of US $\$ 2$ million. ${ }^{28}$ It was spearheaded by Yigael Yadin, an Israeli archaeologist and former Israel

\footnotetext{
${ }^{21}$ Yael Zerubavel, Recovered Roots: Collective Memory and the Making of Israeli National Tradition (Chicago: University of Chicago Press, 1995), 63.

${ }^{22}$ Ibid., 116. See 114-9 for a discussion of the significance of Lamdan's poem in the development of national memory.

${ }^{23}$ Ibid., 63-4.

${ }^{24}$ Ibid., 120-1. Also, for a discussion of the practice of hiking in Israel as a political statement in the context of Israeli settlements, see Michael Feige, "Recovering Authenticity: West-Bank Settlers and the Second Stage of National Archaeology," in Selective Remembrances: Archaeology in the Construction, Commemoration, and Consecration of National Pasts, ed. Philip L. Kohl, Mara Kozelsky, and Nachman Ben-Yehuda (Chicago: University of Chicago Press, 2007), 285-6.

${ }^{25}$ For a detailed examination of Guttman's role in the creation of the Masada myth, see Ben-Yehuda, Masada Myth, 71-82.

${ }^{26}$ Shmaria Gutman, introduction to LiMetzada be-Ikvot ha-Kana'im [To Masada in the zealots' footsteps], by Zvi Ilan (Tel Aviv, 1973), 3. Cited in Yael Zerubavel, "The Politics of Remembrance and the Consumption of Space: Masada in Israeli Memory," in Memory and the Impact of Political Transformation, ed. Daniel J. Walkowitz and Lisa Maya Knauer (Durham: Duke University Press, 2004), 239.

${ }^{27}$ Yael Zerubavel, "The Death of Memory and the Memory of Death: Masada and the Holocaust as Historical Metaphors," Representations 45 (Winter 1994): 72-100.

${ }^{28}$ Nachman Ben-Yehuda, "Excavating Masada: The Politics-Archaeology Connection at Work," in Kohl, Kozelsky, and BenYehuda, Selective Remembrances, 250.
} 
Defense Forces (IDF) chief of staff who evidently had no qualms about prioritizing national memory over science and history:

[Masada's] scientific importance was known to be great. But more than that, Masada represents for all of us in Israel and for many elsewhere, archaeologists and laymen, a symbol of courage, a monument to our great national figures, heroes who chose death over a life of physical and moral serfdom. ${ }^{29}$

Yadin referred to his team of archaeologists and volunteers as "the revivers of Masada," 30 and wrote that the sight of his team's campsite erected next to the ruins of the Romans' campsite expressed "something of the miracle of Israel's renewed sovereignty." 31 A number of scholars have criticized Yadin for allowing his archaeological observations to be biased, arguing that he drew conclusions that could not be convincingly supported by the evidence found during the excavations. ${ }^{32}$ Ben-Yehuda even goes so far as to claim that the Masada excavations were an example of nation-building archaeology that involved "falsifying historical evidence and concealing facts, adapting deceptive techniques, and inventing historical realities" in order to "forge a specific past and hence new national and personal identities." 33

In the early 1950s a tradition developed in which IDF soldiers made pilgrimages to Masada as part of their army training. ${ }^{34}$ This practice evolved into a widespread ritual in which new recruits celebrated the completion of their training by trekking to Masada and being sworn in on the site. ${ }^{35}$ These swearing-in ceremonies typically included inscriptions in fire that read "Masada shall not fall again" as well as a reading of a version of the speech supposedly given by the leader of the Masada Jews before the mass suicide and a ceremony in which soldiers received their first weapons. ${ }^{36}$ In this way, Masada became central to Israeli national identity, symbolizing patriotic loyalty and the willingness to defend one's country to the bitter end. The myth came to be seen as proof of a centuries-old connection between the Jewish people and the land of Israel, giving the impression of historical continuity between the Jews of Masada in the first century and the Jews of the modern state of Israel in the twentieth century. These ideas contributed to the legitimation of the presence of a Jewish state in that land, and reinforced that state's right to exist in the face of hostility from surrounding Arab countries. ${ }^{37}$ Some Israelis even began to speak of their country's "Masada complex," in which the Masada story was seen as a metaphor for Israel's geographical position and political stance. The idea of a Masada complex neatly summarized the negative criticism of Israel that began to emerge inside and outside Israel after the Six-Day War in 1967: that the state was overly defensive, inflexible, uncompromising, and fanatical and that its policies and actions were characterized by a "fortress mentality." 38

\footnotetext{
${ }^{29}$ Yigael Yadin, Masada: Herod's Fortress and the Zealots' Last Stand, trans. Moshe Pearlman (London: Weidenfeld and Nicolson, 1967), 13.

${ }^{30}$ Ibid., 26.

${ }^{31}$ Ibid., 21.

32 See, for example, Ben-Yehuda's detailed examination of Yadin's speculations regarding skeletons found at the site in "Excavating Masada," 260-8.

${ }^{33}$ Ben-Yehuda, Sacrificing Truth: Archaeology and the Myth of Masada (New York: Humanity Books, 2002), 23. Also see BenYehuda, The Masada Myth, 54-68.

${ }^{34}$ See Ben-Yehuda, The Masada Myth, 147-62, for a chapter on Masada and the IDF.

${ }^{35}$ Israel has a policy of compulsory military service for all young people after they finish school. Men serve for three years and women for two.

${ }^{36}$ Ben-Yehuda, The Masada Myth, 152-3.

${ }^{37}$ Baila R. Shargel, “The Evolution of the Masada Myth,” Fudaism 28, no. 3 (1979): 361-2.

${ }^{38}$ Zerubavel, Recovered Roots, 209-213; Shargel, “The Evolution of the Masada Myth," 362-9.
} 
As suggested above, the Masada narrative with which the majority of Israelis are familiar is a national myth that continues to be taught and circulated in Israeli society as history. Scholars agree that the wellknown myth departs in several ways from the original historical event (whose source is already problematic) and many have criticized the myth's significant role in Israeli culture. ${ }^{39}$ First, there is the problem of the original historical source of the story: Josephus Flavius's The Wars of the Jews, in which the mass suicide is related. ${ }^{40}$ No other record of the Masada event exists, making it impossible to authenticate Josephus's version through comparison. Josephus's own personal history provides grounds for treating his account with some skepticism: born and raised a Jew, he surrendered to the Romans during the Jewish Great Revolt, changed his name from Joseph ben Matthias to Josephus Flavius, and was employed as an interpreter and mediator by Titus, future Roman Emperor. Historians argue that these biographical details make it highly likely that Josephus's account was biased in some way; Pierre Vidal-Naquet, for example, writes that it should be read "as a text whose relationship to the event . . is not evident." assume Josephus's account to be relatively accurate, the popular myth is still a distortion of the story related by Josephus.

According to Josephus, the Jews who died on Masada were not freedom fighters who bravely fought against overwhelming odds after being exiled from Jerusalem by the Romans. They were a group called the Sicarii, who were driven out of Jerusalem long before the destruction of that city by the Romans, and they were renowned for carrying out bloody massacres in neighboring villages. Moreover, while the popular version recounts that the Masada Jews fought to defend Masada against the Romans for months or even years before making the decision to commit mass suicide as a last resort, Josephus's account makes no mention of any battles at all and states that the Jews murdered each other under the instructions of their leader (which may or may not be considered suicide, particularly in the case of the women and children on Masada, who would not have taken part in the decision-making process). The elevation of the story to mythical status has also raised questions in Israeli society about Judaism's position in regard to suicide and whether or not it is appropriate to consider a mass suicide as a heroic act that helped to lay the foundations for contemporary Israeli society. ${ }^{42}$

Yet in spite of the problematic aspects of the Masada myth to which many scholars have drawn attention, most Jewish Israelis (and many diaspora Jews) continue to understand the site and its history as a symbol of Jewish heroism: the willingness to "take the last stand" and fight to the death against all odds rather than surrender to capture and humiliation. Even UNESCO's description of the site's significance states that it is "a poignant symbol of the continuing human struggle between oppression and liberty" an unambiguous sign that the myth has been fully absorbed, not only by Israeli society but also by other groups who come into contact with the site.

\footnotetext{
${ }^{39}$ Ben-Yehuda discusses in detail the differences between the historical version and the mythical version and how these came about in Sacrificing Truth, 29-59.

${ }^{40}$ For a complete translation of Josephus's Masada story, see Flavius Josephus, "The Wars of the Jews: Or the History of the Destruction of Jerusalem" in The Works of Josephus: Complete and Unabridged, trans. William Whiston (Peabody, Mass.: Hendrickson Publishers 1987), 762-9.

${ }^{41}$ Pierre Vidal-Naquet, The Jews: History, Memory and the Present, trans. David Ames Curtis (New York: Columbia University Press, 1996), 27. Also see Shargel, "The Evolution of the Masada Myth," 360; Robert Paine, "Masada: A History of a Memory," History and Anthropology 6, no. 4 (1994): 373-6.

${ }^{42}$ Zerubavel, Recovered Roots, 200-7.

43 “Masada: Outstanding Universal Value," UNESCO World Heritage Centre website, accessed 5 July 2012, http://whc.unesco.org/en/list/1040.
} 


\section{Nabucco at Masada, 2010}

Intended to celebrate Israeli Opera's twenty-fifth anniversary, the premiere of Nabucco at Masada took place on June 3, 2010, just three days after Israel found itself embroiled in a political and diplomatic crisis when members of its defense force boarded a flotilla that was attempting to break Israel's blockade of Gaza. The political climate in Israel at this time was tense: Israeli soldiers had shot dead nine activists and wounded many others on the vessel, which had been in international waters, and the incident featured in international headlines for many days afterwards. The situation was, to some extent, an echo of the events of 1988, when the Palestinian uprising caused Nabucco to be cancelled. Except that this time there was no cancellation. The poignant but circumstantial political timing of the event did not escape Opera critic David Mermelstein: "to see this opera depicting ancient Hebrews defeated and enslaved by Babylonians in the midst of a modern-day political crisis qualifies as an indelible memory." 44 Amit Slonim, writing on an Israeli news website, declared the production a "victory" because " 4000 tourists ... came to Israel especially to watch the Israeli Opera perform these five shows, in a week where Israel's name was mentioned in the media for any other reason but culture." ${ }^{45}$ The coinciding of the opera with the Gaza flotilla incident seemed to heighten nationalistic sentiment and evoke hints of the "fortress mentality" for several of the opera's critics and commentators.

The nationalistic vein of the production was enhanced by the appearance on opening night of the Israeli President Shimon Peres, who gave a short speech before the opera began. He set the scene by painting a grand picture of the symbolism of Nabucco and what it meant to perform the work at Masada:

A nation [Israel] that has known redemption, destruction, and resurrection, can now allow itself to speak in terms of eternity ... Destruction-a punishment given to a people who went astray, who no longer travelled the path of faith and good deeds. Redemption is a combination of self-sacrifice and a historical view on events. It is a miracle ...

Masada is a geographical precipice, it is also a historical precipice. It is the ultimate declaration of the choice of freedom over everything, even life itself. From the rivers of Babylon to the gospel of Zion. Here the precipice is used as a backdrop of bravery and glory. Staging Nabucco is a triumphant artistic accomplishment. ${ }^{46}$

One critic commented that when Peres spoke with "moving words about the destruction of the First Temple ... from his trembling voice one would have thought that he was actually there in Jerusalem at that time." 47 The language and images used in this speech conveyed not only a significant national event, but something of biblical proportions. The emotion and immediacy of Peres's words suggested to listeners that they were about to experience proof of Israel's triumphant redemption: performing Nabucco at Masada was a celebration of the Jews' miraculous return to Zion-a resurrection that Verdi himself could never have imagined.

Following rapturous applause for Peres, the audience joined the Israel Symphony Orchestra in a rendition of the national anthem, "Hatikva" (The Hope), which tells of the Jewish soul's yearning to

\footnotetext{
${ }^{44}$ David Mermelstein, “Israel: Masada,” Opera 61, no. 10 (2010): 1261-2.

${ }^{45}$ Some of the reviews I refer to were originally published in Hebrew and have been translated into English for the purposes of my research. Translated reviews will be marked with $(\mathrm{H})$ at the end of the initial footnote. Amit Slonim, "A Different Kind of Opera," Mako, 4 June 2010, http://www.mako.co.il/music-Magazine/articles/Article-db19aedd7440921004.htm (H).

${ }^{46}$ Shimon Peres, "Speech for Nabucco opening night," President of the State of Israel website, 3 June 2010, http://www.president.gov.il/Speeches/Pages/speech_03062010_02.aspx (H).

${ }^{47}$ Slonim, "A Different Kind of Opera."
} 
return to Zion. Although the audience was apparently receptive, the arts critic for the liberal paper Haaretz, Noam Ben Zeev, described conductor Daniel Oren's interpretation as "sickly sweet," and commented sarcastically on "the spirit of nationalism that was selling here like hotcakes." Ben Zeev's more cynical perspective on the entire production indicated an unwillingness to be co-opted into what he evidently viewed as a transparent nation-building exercise. He wrote:

The Israeli Opera ... presented Nabucco as a Jewish opera relevant to our times-about the return to Zion. In this way, a hallucinatory connection was established between Italian nationalism-of which Verdi was one of the chief spokesmen-the exotic nature of the European "grand opera," the Jewish revolt against Rome 600 years after Nebuchadnezzar, and Zionism, some 2,000 years later. ${ }^{48}$

Ben Zeev was the exception among the authors of a collection of reviews that conveyed a generally uncritical participation in the event's blatant nationalism. His review, however, is worth particular note because his perspective is more sophisticated, critical, and reflective than most of the other commentaries examined here.

After Peres's speech and the singing of the national anthem, the opera itself finally began, and brilliant beams of light shot into the sky as the illuminated mountain of Masada became the backdrop for Verdi's tale of triumphant Hebrews (see Figure 1). The technique of lighting the mountain and directing lights into the sky served to incorporate the physical landscape into the world of the opera, and highlighted the importance of place in this operatic event. The multi-level design of the set encouraged a view of the mountain as an extension of the stage, and the powerful beams of light that pointed upwards and outwards broadened the visual scale. In general, light, color and fire were featured strongly throughout the evening, (see Figure 2), and the spectacular thunderbolt that struck down Nabucco at the end of Act II was described by some as the most memorable part of the performance.

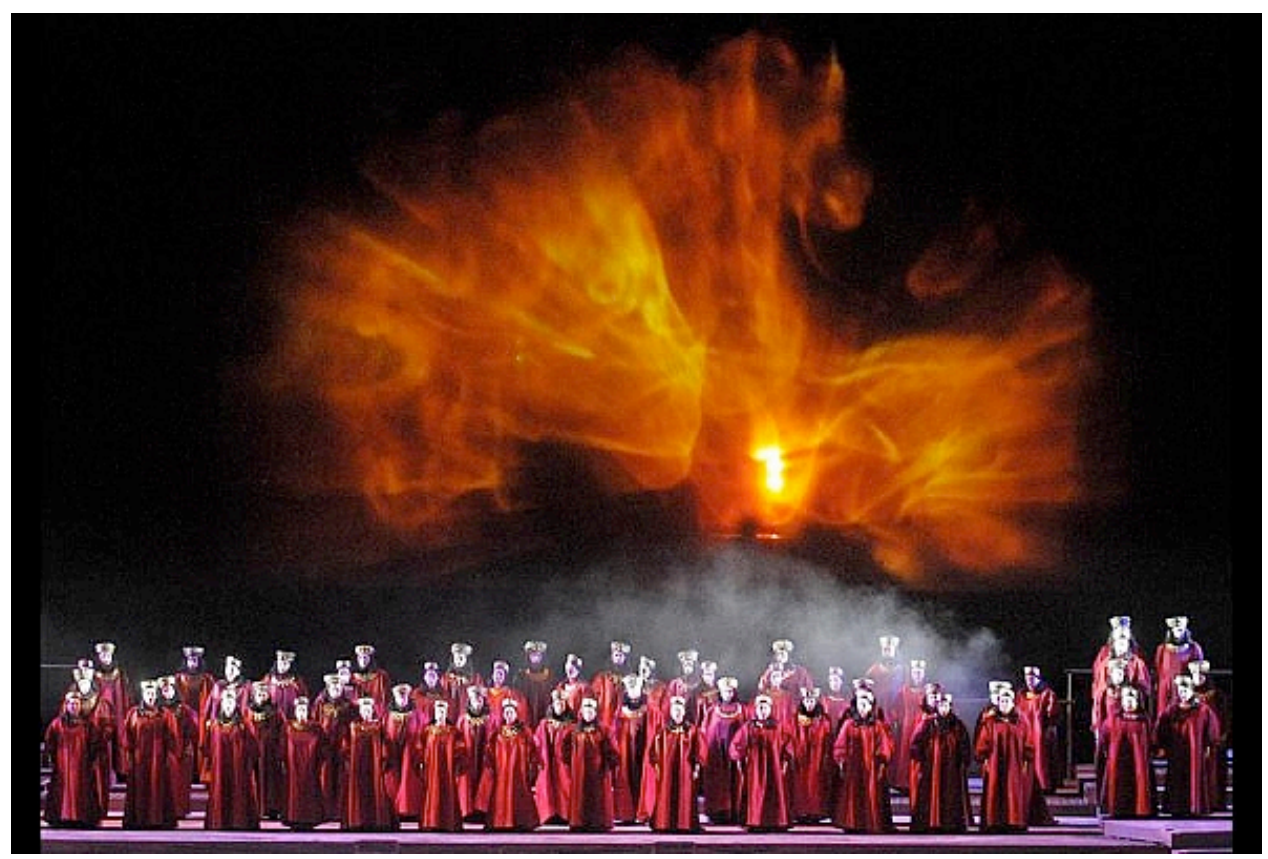

Figure 2: Fire and lighting effects featured strongly in the production. Photograph by Yossi Zwecker

\footnotetext{
${ }^{48}$ Noam Ben Zeev, "Soundbox/Operatic Desert Storm," Haaretz, 7 June 2010, http://www.haaretz.com/culture/artsleisure/soundbox-operatic-desert-storm-1.294585.
} 
The grand spectacle and sheer scale of the production seemed to leave more of an impression on critics than the music or performers - this may have been partly because many of the reports were written by journalists rather than specialist music critics. Performed for 6,500 audience members each night for five nights, the production involved a 60-meter-wide stage, 1,000 lights, 50 generators, more than 100 performers, 12 horses, and even some camels sourced from a local Bedouin tribe. ${ }^{49}$ Indeed, Jerusalem Post critic Ury Eppstein admitted, "The singers seemed to have been a marginal element in the production." ${ }^{\circ 0}$ Many of the critics were simply impressed that the singers were able to sing at all in the face of " 47 degree heat, humidity, wind, dust and sandstorms," ${ }^{51}$ with one critic declaring that the singers' greatest accomplishment was surviving the performance without choking. ${ }^{52}$ They remarked on the sheer practical and technical achievement of staging an opera in the middle of the desert ${ }^{53}$ and-understandably given the unique nature of the event-paid little attention to musical details. When "Va, pensiero" was finally played in Act III, the audience (predictably) called for an encore, which was granted by Oren. Several critics described this as the highlight of the evening and Zvi Goren, writing for Israeli arts online magazine Habama, even described the chorus as "this ultra 'national' piece by Verdi . . 'Va, pensiero,' or for us, 'On the Rivers of Babylon' about longing for a homeland and freedom. ${ }^{, 54}$ But twice was not enough: once the encore was over, rather than proceeding with the rest of Act III, Oren responded to demands for a second encore by turning to the audience with an improvised microphone (see Figure 3), saying, "It is a dream come true to perform this slavery song in this holy place. ${ }^{55} \mathrm{He}$ then invited the audience to join in a third rendition of the chorus.

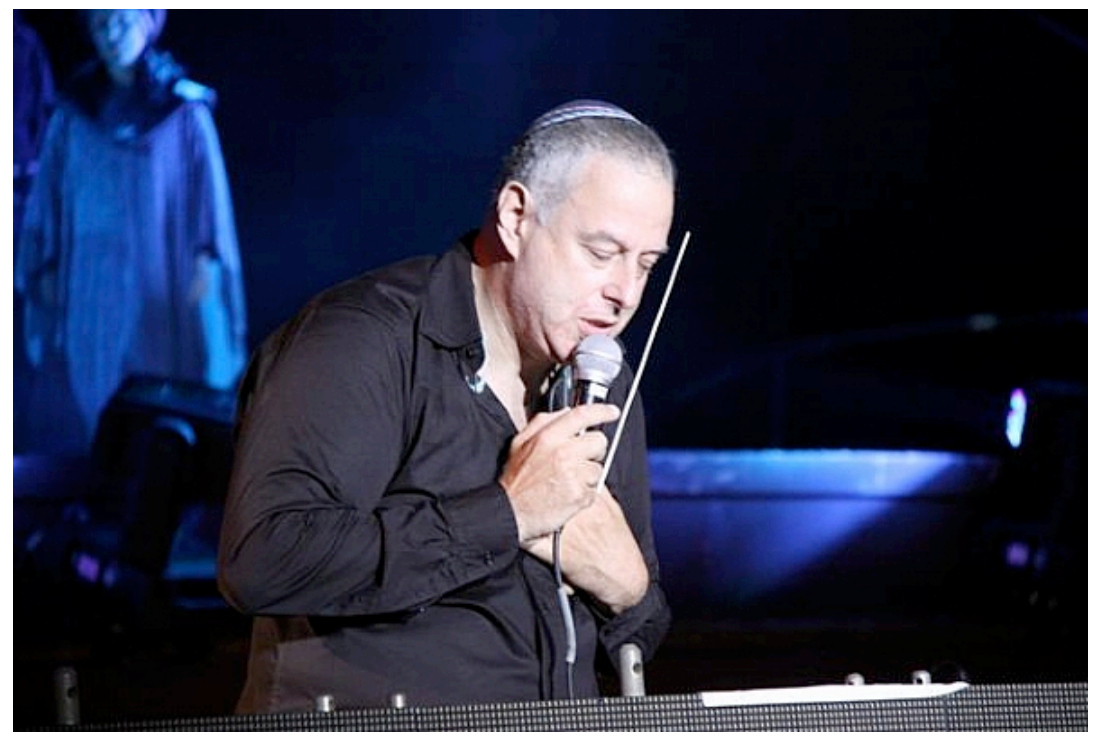

Figure 3: Daniel Oren addresses audience. Photograph by Yosef Avi Yair Engal.

\footnotetext{
${ }^{49}$ Louise Stickland, "Nabucco at Masada," ZioGiorgio.com, 1 January 2011, http://www.ziogiorgio.com/viewnews.php?id=30214.

${ }^{50}$ Ury Eppstein, “The Israeli Opera Verdi: Nabucco Masada, June 3,” The Ferusalem Post, 15 June 2010, http://www.jpost.com/ArtsAndCulture/Music/Article.aspx?id=178551.

${ }^{51}$ Stickland, "Nabucco at Masada."

${ }^{52}$ Mermelstein, "Israel: Masada," 1262.

${ }^{53}$ The production was considered to be such a technical achievement that it featured on ZioGiorgio: a news website for professional sound and light engineers. See Stickland, "Nabucco at Masada."

${ }^{54}$ Zvi Goren, "An Impressive Platform for Artistic Forces," Habama, 1 June 2010,

http://www.habama.co.il/Pages/Description.aspx?Subj=5\&Area=1\&ArticleId =12494 (H).

${ }^{55}$ Slonim, “A Different Kind of Opera."
} 
Most critics described these developments as apparently spontaneous, although Ben Zeev, true to form, denounced it as "a well-orchestrated plot" and described Oren's speech as "so sentimental that it is best not to repeat it here." ${ }^{56}$ Opera's critic was similarly perturbed, writing that it "rankled a foreign visitor" and "really broke the drama's spell." "But," he admitted, "many in the audience seemed to favor the digression." This was a position reflected by most of the Israeli critics, who were not at all disturbed by the interruption. The symbolism of the mountain of Masada towering before the audience as they sang of returning to a Biblical homeland could not have been lost on them, particularly after listening to Peres's patriotic speech and singing the national anthem, all at a time when international criticism of the Israeli government had reached a climax. Merav Yudilevitch seemed to sum up the tone of the majority of the Israeli critics in her review, titled "Masada Shall Not Fall Again," obviously a reference to Lamdan's famous poem. The title signified her intention to draw just the kind of parallels between Masada, Nabucco, and Israel that Ben Zeev termed "hallucinatory." She wrote that the staging of the opera at this site,

helped the opera reverberate aloud under the night sky, in one of Judaism's most symbolic places of bravery and heroism. A nation's struggle for survival, power struggles between leaders and religions, a need for revenge-it was true then as it is true today ... An irresistible combination of a timeless piece coming out of the pages of history to say something larger about life, in the ultimate location, that is the past, the present and the future together. ${ }^{58}$

Oren himself was similarly convinced that the opera was really about Israel and the Jews, declaring in an interview (see Video 2):

I think that Verdi was a big prophet. He knew that [the nation of] Israel will return to his [its] country. He knew it. And we see it with this piece. And he knew that what's important to a person [is] to have a place to live in and to be free in this place...

For the Italians ["Va, pensiero"] is a metaphor. For the Jews it was not a metaphor. They pray every day to return to Jerusalem. For us it's a very emotional opera, it's a very emotional piece and ... the climax for me is "Va, pensiero." 59

For both Oren and number of the Israeli critics, the message of Nabucco was absolutely contemporary and highly political: that the Jewish nation needs to live in freedom in the Holy Land, and that today's Jewish state is simply the just fulfillment of centuries of Jewish longing to return.

Video 2: Interview with conductor Daniel Oren in June 2010.

View at: http://dx.doi.org/10.3998/mp.9460447.0009.103

Since the success of the Nabucco production in 2010, the Israeli Opera has created an annual Masada Opera Festival, which stages a different opera at the foot of Masada each year. ${ }^{60}$ The festival website outlines five main principles that form the rationale behind these expensive and extravagant productions: the Artistic Principle, the Tourism Principle, the Social Principle, the Environmental Principle, and the

\footnotetext{
${ }^{56}$ Ben Zeev, "Soundbox/Operatic Desert Storm."

${ }^{57}$ Mermelstein, "Israel: Masada," 1262.

${ }^{58}$ Merav Yudilevitch, “Masada Shall Not Fall Again,” YNet, 1 June 2010, http://www.ynet.co.il/articles/0,7340,L3897126,00.html (H).

${ }^{59}$ Daniel Oren, "Jewish Opera in the Israeli Desert," interview by Michael Schwartz, CNN Belief Blog, 14 June 2010 , http://religion.blogs.cnn.com/2010/06/14/verdis-jewish-opera/.

${ }^{60}$ The festival featured Aida in 2011 and Carmen in 2012. Turandot was planned for 2013 but then cancelled.
} 
Economic Principle. The festival's Tourism Principle seems to encompass not only tourism concerns but also associated political and diplomatic concerns, stating,

Creating a cultural tourism attraction like our festival becomes a magnet that would no doubt draw culture buffs who tour the world also [sic] to our land. The State of Israel that the average tourist comes to know is different from the country they have learned to [sic] about from the media and from the world of politics. This positive normal image of Israel begins a chain effect that eventually will bring many more tourists to Israel . . ${ }^{61}$

This statement reveals one of the primary motivations behind the Nabucco production, which was performed for thousands of audience members, cost the equivalent of US\$10 million (40 million Israeli shekels) and attracted more than four thousand international tourists who flew in especially for the performance. $^{62}$ Many more would have been exposed to images and reviews of the production through Israeli and international media. The need for Israel to project a more "normal" image of itself to the rest of the world in the context of an increasingly hostile and critical international stance towards the Israeli government was clearly a significant priority for Israeli Opera. ${ }^{63}$ Critic Amit Slonim obviously noticed this aspect of the production, declaring, "The investment of all involved, who from the outset didn't go into it to make a profit, is proof that even in Israel we can build a long-distance cultural project." ${ }^{\prime 64}$

Yet while the festival website indicates an attempt to steer clear of "the media and the world of politics," ${ }^{65}$ the production of Nabucco in 2010 was nothing if not political. People like Daniel Oren were able to send a blatantly political message through this opera because of its long and well-known Italian reception history, which conceives of it as a nationalist work and has created performance traditions that support this conception. It is this history and these traditions that gave the Israeli version its power and that allowed the Israeli Opera to make use of Verdi's opera in such a nationalistic way. Yet its success also depended on removing the Italian metaphor and its associated mythology and returning to an interpretation that was closer to the original plot and was able to exploit a different myth: that of Masada as symbol of Jewish heroism and belonging to the land. The finished product ultimately wove together the ancient and modern histories of the Holy Land with contemporary political tensions between Israel and Palestine, and national collective memory in Israel, as well as elements of Italian nationalism and independence. The positioning of the production in a nationalistic framework began with the president's speech and singing the national anthem and continued with encouraging audience participation in the second encore of "Va, pensiero." As both audience and performers yearned through song for a homeland in the very place for which they were yearning, the imposing presence of Mount Masada behind the desert stage created a powerful symbol and contributed a new and intriguing layer of meaning to the performance and reception history of Verdi's music.

\footnotetext{
61 "The Israeli Opera at Masada," The Masada Festival website, accessed 5 May 2012, http://www.israelopera.co.il/eng/?CategoryID $=499$.

${ }^{62}$ Figures cited in Slonim, "A Different Kind of Opera," and Ben Zeev, "Soundbox/Operatic Desert Storm."

${ }^{63}$ The 2014 Israeli Opera at Masada production of La Traviata was announced in late 2013 as part of a "Year of Friendship" between Israel and Italy, which reportedly involved 12 agreements on diplomatic and political issues, as well as a number of cultural events. See Shlomo Cesana, "Coming in 2014: La Traviata at Masada," Israel Hayom, 3 December 2013.

${ }^{64}$ My italics. Slonim, “A Different Kind of Opera."

65 “The Israeli Opera at Masada," Masada Festival website, http://www.israel-opera.co.il/eng/?CategoryID=499.
} 


\begin{abstract}
This article investigates the performance and reception of an Israeli opera production of Giuseppe Verdi's Nabucco in 2010, staged at the World Heritage site of Masada in the Judaean Desert in Israel. The article examines the ways in which the Italian political and national mythology attached to this work was simultaneously implemented and displaced in order to allow an Israeli nationalist interpretation of the opera. The significance of Masada to Israeli collective memory and national identity, and the way in which this interacted with the mythology surrounding Nabucco, are also explored.
\end{abstract}

